Monika KOSACKA ${ }^{1}$,

Karolina WERNER-LEWANDOWSKA ${ }^{2}$, Paulina GOLIŃSKA-DAWSON ${ }^{3}$

\title{
DEVELOPING FRAMEWORK FOR SUSTAINABILITY INDICATORS SYSTEM (SIS) FOR THE REMANUFACTURING COMPANIES FROM AUTOMOTIVE INDUSTRY- RESEARCH RESULTS
}

The aim of this paper is to provide results of research on the development of Sustainability Indicators System (SIS) for sustainability assessment in remanufacturing companies from automotive industry. Research was carried out within the project "Sustainability in Remanufacturing Operations" (hereafter: SIRO), representing cooperation between Poland and German for sustainable development accomplishment at the Faculty of Engineering Management at the Poznan University of Technology in 2012-2014. Sustainable development (hereafter: SD) is a concept based on three pillars including: Economy, Environment and Society, which remain in the trade-off relationship to each other. This implies difficulties in implementing the SD concept. Another equally important issue is the difficulty of the activities' assessment of compatibility with the basis of the concept. Authors state that, in order to realize the SD concept at the company level, the development of the measurement system is required. In the first place, it provides the assessment of the actual state, with simultaneous determining the course of future actions. To address this challenge, authors in the result of conducted research propose SIS consisted of 15 indicators suitable for integrated $\mathrm{SD}$ assessment. It was assumed that there is lack of appropriate indicators set capable to address integrated SD assessment at the remanufacturing company level. Previous studies present the opportunity to evaluate the different SD pillars, however, the disadvantage of these solutions is the multiplicity and unclarity of the proposed methodology. Therefore, as part of the study, the authors propose a clear methodology of sustainability assessment for remanufacturing companies.

Keywords: sustainable development, sustainability assessment, sustainability indicator system

\section{INTRODUCTION}

„Sustainable development" is recent issue, which according to Tan et al. is “a hot issue for nations, companies and individuals" [Tan et al. 2015, p. 132].

\footnotetext{
1 Monika Kosacka, Msc, Eng., Faculty of Engineering Management Poznan University of Technology, ul. Strzelecka11, 90-695 Poznań, tel. 6166534 14, monika.kosacka@ put.poznan.pl

2 Corresponding author, Karolina Werner-Lewandowska, PhD, Eng., Faculty of Engineering Management Poznan University of Technology, Poznań, ul. Strzelecka11, 90-695 Poznań, tel. 616653414 , karolina.werner@put.poznan.pl

${ }^{3}$ Paulina Golińska-Dawson, PhD, Eng., Faculty of Engineering Management Poznan University of Technology, ul. Strzelecka11, 90-695 Poznań, tel. 6166534 14, paulina.golinska@put.poznan.pl
} 
SD has its roots in ideas about sustainable forest management which were developed in Europe nineteenth century. The essential issue was to manage the process of tree cutting considering the possibility of reforestation, providing the ability to restore the forest [Pittel 2004, p. 537].

It took some time and the concept was introduced to the worldwide debate - in the early 1970s, drawing attention to man's over-exploitation of the environment, with the focus on economic development. In the result, SD was incorporated into many research areas including: economy, philosophy, politics, engineering, etc., what led to many different definitions of the problematic issue [Wodzikowski 2009, p. 84].

Based on inventory of different definitions of $\mathrm{SD}^{4}$, it was stated, that there is lack of clear and common for each research area, designation of SD, what would be convincing for everyone [Möller, 2013. p. 69]. That issue becomes the cause of SD critics, which was described by Kudłak [Kudłak 2008, p. 19]. The paper included one of the most widely recognized definitions of SD following the Brundtland Report: "Sustainable development is development which meets the needs of the present without compromising the ability of future generations to meet their own needs" [WCED, 1987].

In order to make the SD more specific, there was made a literature review of chosen definitions resulting in the list of SD concept features, including [Bartkowiak 2010, Piontek 2002, pp. 16-27; Kistowski 2003, pp. 31-34, Diefenbacher 2001, p. 65]:

- Type of development: social-economic (developed by human),

- Exposure time: long time horizon including future generations (the focus on longterm nature),

- The principle of intergenerational justice,

- Process characteristics: SD is an integrated process of human activities in various activities,

- Objective: balancing the three pillars ${ }^{5}$ : people, environment, economy.

Considering the SD concept, it is required to refer to three sustainability pillars, including economy, environment and people.

Pillar „ECONOMY” is an economic component, expressing the classic striving to achieve prosperity in material approach. As a result, it becomes necessary to carry out economic development, resulting in an actual increase of wealth [Śleszyński 2007, p. 100]. This pillar is associated with the enlargement of capital, both financial and physical.

Pillar „PEOPLE” it is related to the provision of equal opportunities of development and meeting the needs of the people (mostly elementary needs such as health, access to water, education, shelter, etc.) [Śleszyński 2007, p. 100]. From a social point of view, it plays an important role to ensure security

Pillar „ENVIRONMENT” is focused on maintaining the „environmental infrastructure" as well as long-term ,ecologic productivity”. Śleszyński claims that, on the environmental resources should be used to avoid the disorganization of the relationship between the elements of the environment, and on the other hand, not to reduce their contri-

\footnotetext{
${ }^{4}$ In Polish literature Jeżowski pointed out 100 different SD definitions [Jeżowski 2007, p. 11], Piontek distinguished 44 SD explainations [Piontek 2002, pp. 16-26].

${ }^{5}$ Some of the research stated that ,three pillars" concept is out-of-date. For instance Siemiński distinguished the following aspects of SD: socio-cultural, economic, environmental, spatial, technical-technological and ethical [Siemiński 2008, p.178], while Borys added to traditional configuration two dimensions: spatial and institutional [Borys 2005, p. 48]. In the paper there was used a traditional „three pillars” concept.
} 
bution to the creation of human wellbeing [Śleszyński 2007, p. 100]. The quality of natural resources should not be worse, what is a result of the intergenerational justice (access to a variety of resources for different generations).

The key point in the meaning of the SD concept is to provide a balance between development of each sustainability pillar that the development of one of them did not cause adverse changes in the other dimensions. Mikłaszewski noted that this feature becomes a source of mistakes in the SD concept understanding. It results in the following way of thinking: "the same percentage increase in spending on industrial development and environmental protection" [Mikłaszewski 2000, p. 39].

In the field of sustainable development, there are many major challenges to be addressed. One of the major problematic issue is a trade-off relationships between elements making up the SD system. A 'trade-off' is defined as an exchange of one thing in return for another one.

Enterprises undertaking technology investments related to the reduction of emissions (environmental aspect) or related to the improvement of Employees working conditions (social aspect) expend founds which become profit for owners (economic aspect). This leads to reduction of the profit of the owner, of which the economic aspect of the business activity is assessed. Thus, the economic aspect is often considered as a priority one, while the other pillars of SD are used as a servant in relation to him. There were many papers about the trade-off relations including: [Brent \& Labuschagne, 2006], [Assefa \& Frostell, 2007], [McKenzie, 2004].

Simultaneously to the trade-off relationship, there are different positions, that undermine these conflicts. According to Famielec, there is no conflict between economic and social objectives. [Famielec 2005], as the commitment to the social objectives may result in the achievement of economic goals (eg. Improvement of working conditions for employees can help to improve their effectiveness). The second conflict in the system: economy-environment is also a stereotype, which was observed in 1991 by Porter, arguing that there is a positive relationship between the growth of the environmental requirements and improving the competitiveness of enterprises [Porter 1991 p.168]. It may be confirmed by the installation of low-energy and low-waste technology, which in the long time horizon will be translated into lower costs.

The paper intends to present the comprehensive and practical indicator framework for sustainability assessment for car remanufacturing companies in Poland.

The remaining part of this paper is structured in the following way: Section 2 presents an overview of sustainability concept introduction at the company level. There were presented premises for incorporating sustainability into company strategy and the meaningful of sustainable enterprise. Section 3 introduces sustainability assessment as an essential part of SD. In section 4 indicators for assessing a SD at the company level were described. In section 5, the SIS framework is presented. Finally, there is included summary of the paper.

\section{SUSTAINABILITY AT THE COMPANY LEVEL}

Sustainability is an essential goal for governments, industry, companies, farms, etc. Authors focused in the paper on the company level. Researchers presented research results related to the evaluation of sustainability indicators for companies processing End of Life 
vehicles, which are car remanufacturing companies. It was assumed that the study branch is performing the SD concept.

The introduction SD at the company level is an object of scientific discussion, which devotes more attention ${ }^{6}$. The realization of SD at the company level was popularized by the foundation of the World Business Council for Sustainable Development (WBCSD) and the International Institute for Sustainable Development (IISD) [Hejduk, Grudzewski 2014]. Assumptions about the concept at the enterprise-level, concern [Hejduk, Grudzewski 2014]:

- Ecoeffectiveness - production of goods /services that meet customer needs and improve their quality of life,

- Innovation and technology,

- Corporate social responsibility with regard to ecosystems, the health and safety of employees and customers of goods / services.

The company which follows pointed assumptions (is sustainable) is running a business in different manner than traditional one, what was presented in the Table 1.

Table 1. Comparison between traditional and sustainable enterprise

\begin{tabular}{|l|l|l|}
\hline Comparison feature & Traditional enterprise & Sustainable enterprise \\
\hline Objective & Profit maximization & $\begin{array}{l}\text { Growth and sustainable development, care } \\
\text { for the welfare of stakeholders and the envi- } \\
\text { ronment }\end{array}$ \\
\hline $\begin{array}{l}\text { Approach to the } \\
\text { Environment }\end{array}$ & $\begin{array}{l}\text { Source of raw materials, } \\
\text { which should be used } \\
\text { (overexploitation) }\end{array}$ & $\begin{array}{l}\text { Resource source, including non-renewable, } \\
\text { which should be saved. Taking action in } \\
\text { harmony with nature }\end{array}$ \\
\hline Future vision & $\begin{array}{l}\text { Limited to the planning } \\
\text { horizon }\end{array}$ & $\begin{array}{l}\text { Long-term, with taking under consideration } \\
\text { needs of future generations }\end{array}$ \\
\hline Values & Material, rational & Immaterial, socio-ecological \\
\hline $\begin{array}{l}\text { Priority of meeting } \\
\text { needs }\end{array}$ & Company owner & $\begin{array}{l}\text { Integration in meeting the needs of all stake- } \\
\text { holders }\end{array}$ \\
\hline
\end{tabular}

Source: own elaboration based on [Raftowicz-Filipkiewicz 2013, p. 52]

Taking into account presented comparison of the traditional and sustainable company it was noticed, that modern enterprise that follow the implementation of SD is not aimed to maximize profits, which is characteristic for the traditional approach [Friedman 1970]. Currently we recognize the growing importance of intangible assets, respect for nature and creating good conditions for work and life of the people, at the expense of tangible assets (mostly financial). Moreover instead of focus on owner's needs, the company is oriented on integrating the needs of all company's stakeholders.

The authors indicated that simultaneously to the evolution of the approach to the role of the company, the attitude to the practical implementation of the principles of sustainable development in business activities was changing.

\footnotetext{
${ }^{6}$ The issue is discussed in international journals including: „Journal of Sustainability and Green Business”, „Journal of Social Business” [Dobrzański and Szymańska, 2013]. There was observed domination of English publication, although there were some attempts on Polish market to reference the SD concept of business enterprises, such as the works of the following authors: Przychodzień or Jabłoński [Dobrzański and Szymańska, 2013].
} 
Originally, the company implementing the assumptions of SD took actions related to the protection of the environment ${ }^{7}$. This involved carrying out activities aimed to reduce emissions of pollutants into the environment, waste reduction or resource efficiency. Currently, environmental issues are included into strategy of companies in the framework of environmental management systems such as ISO 14001 or EMAS, which have a wide range of influence [Ogrodnik 2011, p. 181]. Social issues however are carried out within the framework of CSR strategy ${ }^{8}$. The catalogue of currently undertaken actions in the framework of sustainable development includes as following [Szadziewska 2010]:

- rational use of natural resources,

- prevention of negative effects on the environment by the use of new environmentally friendly technologies and equipment reducing the amount of pollutants,

- undertaking initiatives to support local communities;

- attention to product quality,

- investments in environmental protection projects,

- ethic in relations with stakeholders of the company.

The concept of SD is often included in the strategy of the company. The basic reason is that it is seen as the basis for building competitive advantage.

The correlation between the implementation of SD strategies, and competitiveness increase is point of contention in the scientific community. According Wasiak and Dobrzański companies more frequently take the initiative related to the implementation of sustainable development, by introducing solutions that make it possible to meet the social and environmental demands in advance [Wasiak and Dobrzański 2005, p. 10], before there appear legal requirements. Przychodzień proved in his research on companies listed on the Warsaw Stock Exchange, that investment in sustainable development bring the expected benefits in terms of improved competitiveness [Przychodzień 2013]. Similar conclusions can be drawn based on the research carried out by Kudłak [Kudłak 2008]. Taking into account all presented information, it was assumed that there is a positive correlation between the implementation of sustainable development at business activity of the company and their competitiveness.

Apart from the internal SD aspiration, there are other premises for including SD concept into business activity. The basic sustainability drivers arise from economic confirmation and they are related to the environment protection.

First significant factor, become legal requirements. Sustainable development policy implemented at the country and organization level strengthens the favorable market trends and corrects the phenomena that are unfavorable. Lack of compliance with the law requirements is burdened with legal sanctions in the form of fines. In accordance to the law, there are also fees for air emissions or landfill, what stimulates less harmful company activities for the [Bernaciak and Gaczek, 2002, p. 276]. It resulted in carrying out proenvironmental actions, although the grounds lies in law compulsion. What is more, those actions are not always the result of deliberate actions in this direction, but may result from other causes, such as the desire to improve product quality and lower production costs

\footnotetext{
${ }^{7}$ Kozłowski believed that the implementation of SD in practice is equal to reducing dependence on nonrenewable sources of energy, reducing emissions of harmful substances into the atmosphere and reducing emissions of toxic pollutants into water and soil [Kozłowski 1992].

${ }^{8}$ This strategy is sometimes mistakenly considered by some scientists equivalent to SD, despite the distinct theoretical foundations [Przychodzień, Przychodzień 2011, p. 59].
} 
[Bernaciak and Gaczek, 2002, p.276]. However, in the face of increasing environmental pollution, all actions in this area are important, regardless of the accompanying genesis.

Another SD driver is increasing awareness of customers, who are looking for environmentally friendly products, manufactured under suitable conditions [Bernaciak and Gaczek, 2002, p. 276].

This argues that in the near future, the concept of sustainable development will be present and required in each company.

To sum up this chapter, authors cited Nidumolu et al. "There is no alternative for $S D^{\prime \prime}$ [Nidumolu et al., 2009].

\section{SUSTAINABILITY ASSESSMENT - ESSENTIAL PART OF SD}

According to Ness et al. "The purpose of sustainability assessment is to provide decision-makers with an evaluation of global to local integrated nature-society systems in short and long term perspectives in order to assist them to determine which actions should or should not be taken in attempt to make society sustainable" [Ness et al., 2007, p. 499]. To sum up, it is necessary to improve sustainability, what requires knowledge of the actual "sustainability situation", what is equal to measurement requirement.

Sustainability assessment is something natural in the authors opinion. Taking into consideration the statement that "SD is the leading value", there are required for decision makers at different levels of sustainability realization (global, country, company, etc.) information about the current "SD state", in order to focus efforts on actions aimed at improving the social, economic and environmental aspect. SD measurement allows to monitor the progress of its implementation on the improvement road towards a better future for the next generations. Sustainability assessment is a rapidly growing area in the literature, what may be confirmed by the data in Table 2 .

Table 2 Distribution of papers related to the SD assessment in selected scientific bases

\begin{tabular}{|c|c|c|c|c|c|}
\hline \multirow[t]{2}{*}{ Keywords } & \multirow{2}{*}{$\begin{array}{l}\text { PL - } \\
\text { Polish }\end{array}$} & \multirow{2}{*}{$\begin{array}{l}\text { EN - } \\
\text { English }\end{array}$} & \multicolumn{3}{|c|}{ Number of results ${ }^{9}$} \\
\hline & & & SCOPUS $^{10}$ & Google scholar $^{11}$ & BazTech \\
\hline \multirow{2}{*}{$\begin{array}{l}\text { "Sustainability as- } \\
\text { sessment" }\end{array}$} & & $X$ & 708 & 3000 & 6 \\
\hline & $X$ & & - & 8 & 2 \\
\hline \multirow{2}{*}{$\begin{array}{l}\text { „Sustianability measu- } \\
\text { rement” }\end{array}$} & & $\mathrm{X}$ & 63 & 82 & 0 \\
\hline & $\mathrm{X}$ & & - & 5 & 0 \\
\hline \multirow{2}{*}{$\begin{array}{l}\text { "Sustainability indica- } \\
\text { tors" }\end{array}$} & & $X$ & 395 & 1170 & 2 \\
\hline & $\mathrm{X}$ & & - & 33 & 2 \\
\hline
\end{tabular}

Source: own elaboration

There were reviewed papers from journals and sources by searching Title with the keywords presented in the Table 2 (in English and Polish). Authors selected two international well-known databases (SCOPUS and Google Scholar) as well as one Polish (BazTech). It should be noticed that there is a research gap in Polish studies which are mainly theoretical consideration of the SD application at the country or region level asso-

\footnotetext{
${ }^{9}$ Searching results for the date: 08.04 .2016

${ }^{10}$ Searching limitations: Social Sciences \& Humanities

${ }^{11}$ Lack of searching limitations
} 
ciated with the transportation, agriculture, tourism and public administration topics. There are much more papers in English.

Authors are focused on the sustainability assessment with the use of indicators, which are an example of the techniques and tools for SD assessment [Ness et al. 2007]. In accordance to the Agenda $21^{12}$ requirements, there should be established indicators for sustainability measuring: "Indicators of sustainable development need to be developed to provide solid bases for decision-making at all levels and to contribute to a self-regulating sustainability of integrated environment and development systems" [US, 1992, chapter 40.4]

That was the most relevant factor for sustainability indicators system development.

Authors were focused on assessing sustainability at the company level. As Moldavska and Welo highlighted "if we cannot measure the level of the sustainability on the company level, we do not know if we do the right things and are heading in the right direction with our improvement initiatives" [Moldavska \& Welo, 2015]. Concluding, there is a demand on sustainability indicators system for SD measurement at the company level.

\section{SUSTAINABILITY INDICATOR}

In the management, controlling is one of core activities. During the control, there is made verification of the degree of the goals realization, what requires measuring performance [Griffin, 2010, p. 662]. It is possible with the use of indicators.

The measurement requirement was expressed by the principle: "If something cannot be measured, it cannot by managed" [Cooper \& Edgett 2008 Ehrenfeld 2008]. Authors assumed that SD was managed, what required measurement. In order to measure SD, there should be established the sustainability indicators system.

Indicators are useful and relevant tool to track progress over time and identify problems with improvements potential [Tan et al. 2015, p. 132].

Authors defined indicators as "the operational representation of an attribute (quality, characteristic, property) of a given system, by a quantitative or qualitative variable (for example numbers, graphics, colors, symbols) (or function of variables), including its value, related to a reference value" [Waas et al. 2014, p. 5520]. The cited definition is not only useful theoretically, but also practically [Tom Waas i inni, 2014. s. 5520].

Most of the objects /phenomena that are measured are systems. From a technical perspective, an indicator is a variable or an aggregation/function of variables, related to a reference value [Gallopin 1997]. As it was pointed out by Lancker et al. "[...] a given indicator doesn't say anything about sustainability, unless a reference value [...] is given to it" [Lancker and Nijkamp, 2000]. The reference value could be a goal, a target, a norm, a standard or a benchmark [Gallopin 1997].

The importance of indicators is the best described by Abraham Lincoln who stated that: if we could first know where we are, and whither we are tending, we could better judge what to do, and how to do it" [Meadows 1998, p.1].

Indicators are source of information used to understand the world, plan actions and make some decisions [Meadows, 1998], what makes them important in management. Authors believed that the success of the company is no longer measured by financial and

\footnotetext{
${ }^{12}$ The action plan of the United Nations with regard to SD
} 
economic indicators, but by more holistic measurement which includes social, economic and environmental aspects - sustainability indicators.

A literature review shows that several efforts have been made to develop SIS for the application at the company level (for instance: [Tan et al., 2015], [Azapagic, 2004], [Singh et al., 2016]). However identifying a suitable sustainability indicator system is a major challenge. There are many examples of indicators systems which are dedicated for selected business sector, type of the company (including the company size), etc.

Previous studies showed the following list of challenges related to the SIS establishment, including [Moldavska \& Welo, 2015, pp. 621-623; Tan et al. 2015, pp.132-133; Azapagic 2004]:

- $\mathrm{C} 1$ - Addressing three sustainability pillars equally;

- $\mathrm{C} 2$ - Create the system balanced in terms level of generality, complexity, and practical dimension of the measurement;

- C3 -To provide useful information for internal decision- makers;

- C4 - Cost of SIS implementation;

- C5 - Mixing types of indicators (including qualitative and quantitative);

- C6 - Time of the assessment (resource consumption problem);

- C7 - Lack of linkage between sustainability assessment tool and sustainability practice

In the authors opinion, the most important thing is to create the dedicated site-specific SIS capable to address company needs while considering the company as a system and allow the holistic assessment with all sustainability pillars.

\section{SUSTAINABILITY INDICATORS SYSTEM FOR REMANUFACTURING COMPANIES}

This part of paper will discuss: criteria for indicators selection, indicator selection method, elements of indicators and finally, description of SIS for remanufacturing companies.

\subsection{Criteria for "good indicator"}

In the literature there are considered criteria which indicators should comply with in given conditions (called by authors as "good indicator features").

Previous studies provided many guidelines in that area, which were commonly expressed in the form of acronyms including - SMART [Lawler \& Bilson, 2013 s.84-85], SPICED [Roche 1999] or CREAM [Schiavo Campo \& 1999]. In authors opinion that attributes of good indicator should take into account the specific features of the measured system.

In the result of conducted research, there was proposed catalogue of guidelines for the good sustainability indicator at the company level. It was called in the form of acronym ACRUS, created by the first letters of selected features, including [Kosacka, 2014]:

- A - Availability of data: there should be used easy available data, do not create additional demand for data (it is particularly important for small and medium size companies), to ensure short time for the indicators evaluation; 
- $\mathbf{C}$ - Comparability: policy makers need to be able to compare the results of indicator both - over the time (to identify trends) and to compare with others (benchmarking);

- $\mathbf{R}$ - Reliability/Relevance: indicator should provide reliable information required for the implementation of sustainable development policies. It should be directly relevant to continuous sustainability improvement.

- $\mathbf{U}$ - Usefulness: indicator should present the current, complete picture of the situation in the company in a given area. It should be free from excessive data and it should be necessary from the perspective of making further management decisions. It should be applicable to assess industry.

- $\mathbf{S}$-Simplicity: indicator should be simple and logical, both in the construction and interpretation, enabling non-expert understanding and interpreting it in order to make future decisions.

For authors each requirement is equally important.

\subsection{Indicators' selection method}

Authors have developed the method of indicators selection, presented in the Figure 1.

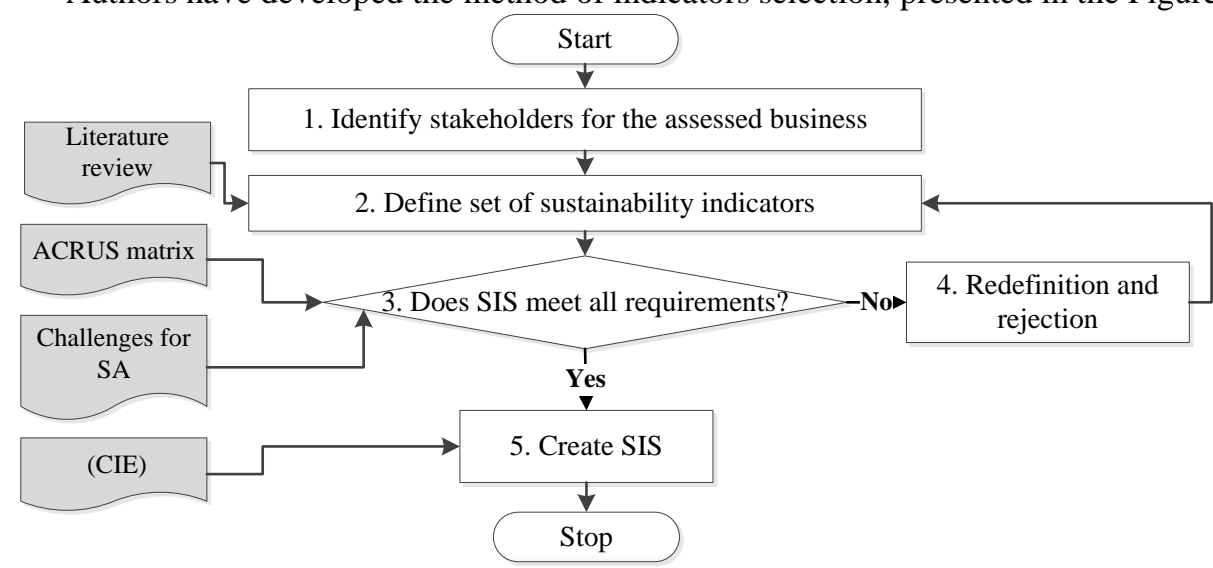

Fig.1 SIS selection method

Source: own elaboration based on [Kosacka, 2014]

The first step is to define stakeholders of the assessed system (company). For the remanufacturing companies, objects which are affected by or on which they have influence on, were: suppliers, customers; employees, competitors, local community and government.

At the step 2, with the information about stakeholders, there is defined a set of indicators divided into the following sub-categories: economic, ecologic, social in order to achieve the holistic view of sustainability in the assessment. This step should involve stakeholders which become experts. At this stage are also included data obtained from the literature review.

Step 3 includes verification of the proposed SIS in accordance to the ACRUS requirements (ACRUS matrix presented in the Table 3) and taking into account pointed out earlier list of challenges for sustainability assessment (in chapter 4). 
Moreover the number of indicators in SIS should be as little as possible to present all required dimensions of SD at the company level. Authors have proposed a system consisted of 15 indicators.

Table 3. ACRUS matrix

\begin{tabular}{|l|c|c|c|c|}
\hline \multicolumn{1}{|c|}{ ACRUS feature } & $\mathbf{I}_{\mathbf{1}} \mathbf{1 3}^{\mathbf{3}}$ & $\mathbf{I}_{\mathbf{2}}$ & $\ldots$ & $\mathbf{I}_{\mathbf{n}}$ \\
\hline $\mathbf{A}$ & & & & \\
\hline $\mathbf{C}$ & & & & \\
\hline $\mathbf{R}$ & & & & \\
\hline $\mathbf{U}$ & & & & \\
\hline $\mathbf{S}$ Number of features (max 5) & 15 & & & \\
\hline
\end{tabular}

Source: own elaboration

The next step is to redefine all indicators which do not fulfill the requirements in accordance to the results obtained of the ACRUS matrix. Indicators which do not comply with presented criteria are rejected. Indicators which meet all requirements (with the total maximum number of features) are selected to SIS.

In the last step, indicators are described according to the Catalogue of the indicator's elements (Hereafter: CIE), presented in the Table 4:

Table 4 Catalogue of the indicator's elements

\begin{tabular}{|l|l|}
\hline Indicator's element & What does it includes? \\
\hline Title & Short description of the indicator \\
\hline Definition & Detailed, clear description of the indicator \\
\hline Measurement & Formula or assessment base \\
\hline Unit & Unit of indicator's value \\
\hline Reference value & Desired value (improvement goal) \\
\hline
\end{tabular}

Source: own elaboration

There could be added also information about required data to provide the assessment and the frequency of measurement.

\subsection{Sustainability indicators system for remanufacturing companies}

Authors, as a result of conducted literature studies, indicates that there is a research gap related to the sustainability assessment in recycling companies.

In accordance to the presented procedure in the Fig. 1 there was prepared SIS for recycling companies, consisting of 15 indicators, what was presented in the Table 5:

\footnotetext{
${ }^{13}$ where $\mathbf{I}_{\mathbf{n}}$ stand as n-th indicator (I)
} 
Developing framework for sustainability indicators system...

Table 5 Sustainability indicators system for remanufacturing companies in Poland

\begin{tabular}{|c|c|c|c|c|c|}
\hline No & Indicator & Description & Formula/assessment base & Unit & $\begin{array}{l}\text { Reference } \\
\text { value }\end{array}$ \\
\hline \multicolumn{6}{|c|}{ Economic performance } \\
\hline 1 & OEE & $\begin{array}{l}\text { Overall Equipment } \\
\text { Effectiveness }\end{array}$ & Availability rate $\times$ Quality rate $\times$ Performance rate & $\%$ & $100 \%$ \\
\hline 2 & RPF & $\begin{array}{l}\text { Remanufacturing pro- } \\
\text { cess flow }\end{array}$ & Quantitative assessment - expert's questionnaire & $1-5$ & 5 \\
\hline \multirow[t]{2}{*}{3} & \multirow{2}{*}{$\begin{array}{l}\text { Planning } \\
\text { adequ- } \\
\text { acy }\end{array}$} & \multirow{2}{*}{$\begin{array}{l}\text { Adequacy of reman } \\
\text { process planning }\end{array}$} & Planned bach remanufacturing lead time & \multirow[t]{2}{*}{$\%$} & \multirow[t]{2}{*}{$100 \%$} \\
\hline & & & Real batch remanufacturing lead time & & \\
\hline 4 & AMT & $\begin{array}{l}\text { Availability of machines } \\
\text { and tools }\end{array}$ & Quantitative assessment - expert's questionnaire & $1-5$ & 5 \\
\hline \multirow[t]{2}{*}{5} & \multirow{2}{*}{$\begin{array}{l}\text { Service } \\
\text { level }\end{array}$} & \multirow[t]{2}{*}{ Level of executed orders } & Number of executed orders in period $t$ & \multirow[t]{2}{*}{$\%$} & \multirow[t]{2}{*}{$100 \%$} \\
\hline & & & Total number of planned orders in period $t$ & & \\
\hline 6 & OOS & $\begin{array}{l}\text { Availability of materials } \\
\text { (overall out of stock) }\end{array}$ & Quantitative assessment - expert's questionnaire & $1-5$ & 5 \\
\hline
\end{tabular}

Environmental performance

\begin{tabular}{|c|c|c|c|c|c|}
\hline 7 & $\begin{array}{l}\text { Energy } \\
\text { consump } \\
\text { sump- } \\
\text { tion } \\
\text { level }\end{array}$ & $\begin{array}{l}\text { Energy consumption per } \\
\text { core }\end{array}$ & Quantitative assessment - expert's questionnaire & $1-5$ & 1 \\
\hline \multirow[t]{2}{*}{8} & \multirow{2}{*}{$\begin{array}{l}\text { Waste } \\
\text { genera- } \\
\text { tion } \\
\text { level }\end{array}$} & \multirow{2}{*}{$\begin{array}{l}\text { Amount of generated } \\
\text { waste }\end{array}$} & Amount ofwaste in period $t$ & \multirow[t]{2}{*}{$\%$} & \multirow[t]{2}{*}{$0 \%$} \\
\hline & & & $\overline{\text { Amount ofmaterial used for production in period } t} \times 100 \%$ & & \\
\hline \multirow[t]{2}{*}{9} & \multirow[t]{2}{*}{ MRR } & \multirow[t]{2}{*}{ Material recovery rate } & Number of recovered cores in period $t$ & \multirow[t]{2}{*}{$\%$} & \multirow[t]{2}{*}{$100 \%$} \\
\hline & & & Number of cores entered to process in period $t$ & & \\
\hline \multirow[t]{3}{*}{10} & \multirow{2}{*}{$\begin{array}{l}\text { Genera- } \\
\text { ted } \\
\text { Emis- } \\
\text { sions } \\
\text { level }\end{array}$} & \multirow{2}{*}{$\begin{array}{l}\text { Amount of emissions } \\
\text { (CO2, water, sewage) } \\
\text { per one regenerated } \\
\text { core (product) }\end{array}$} & Amount of emissions in periodt & \multirow[t]{2}{*}{$\%$} & \multirow[t]{2}{*}{$0 \%$} \\
\hline & & & (Amount ofcores remanufactured $\times$ weight ofcore) in period $t$ & & \\
\hline & \multicolumn{5}{|c|}{ Social performance } \\
\hline \multirow[t]{2}{*}{11} & \multirow{2}{*}{$\begin{array}{l}\text { Employ- } \\
\text { ploy- } \\
\text { ment }\end{array}$} & \multirow{2}{*}{$\begin{array}{l}\text { Change in the level of } \\
\text { employment in the } \\
\text { period }\end{array}$} & Number of executed orders in period $t$ & \multirow[t]{2}{*}{$\%$} & \multirow[t]{2}{*}{$>100 \%$} \\
\hline & & & $\overline{\text { Total number of planned orders in period } t}$ & & \\
\hline
\end{tabular}




\begin{tabular}{|c|c|c|c|c|c|}
\hline No & Indicator & Description & Formula/assessment base & Unit & $\begin{array}{l}\text { Reference } \\
\text { value }\end{array}$ \\
\hline \multirow[t]{2}{*}{12} & \multirow{2}{*}{$\begin{array}{l}\text { Staff } \\
\text { Training }\end{array}$} & \multirow{2}{*}{$\begin{array}{l}\text { Percentage of employ- } \\
\text { ees who participated in } \\
\text { additional training }\end{array}$} & Number of employees in training in period $t$ & \multirow[t]{2}{*}{$\%$} & \multirow[t]{2}{*}{$100 \%$} \\
\hline & & & Total number of employees in period $t$ & & \\
\hline \multirow[t]{3}{*}{13} & \multirow{3}{*}{$\begin{array}{l}\text { Harm- } \\
\text { fulness } \\
\text { of the } \\
\text { remanu- } \\
\text { facturing } \\
\text { process }\end{array}$} & \multirow{3}{*}{$\begin{array}{l}\text { Refers to the conse- } \\
\text { quences that are associ- } \\
\text { ated with threat to safe } \\
\text { and health of workers in } \\
\text { the remanufacturing } \\
\text { process }\end{array}$} & $W=\sum_{i=1}^{N}(300 D+10 S+M) \times L_{i}$ & \multirow[t]{3}{*}{$1-5$} & \multirow[t]{3}{*}{1} \\
\hline & & & Grading scale for $\mathrm{W}$, where: & & \\
\hline & & & $\begin{array}{l}W<10-\text { grade }: 1,100>W>=10-\text { grade: } 2 \text {, } \\
300>W>=100 \text { - grade: } 3,1500>W>=300- \\
\text { grade: } 4, W>=1500 \text { - grade: } 5\end{array}$ & & \\
\hline \multirow[t]{2}{*}{14} & \multirow{2}{*}{$\begin{array}{l}\text { Average } \\
\text { level of } \\
\text { comfort } \\
\text { at work }\end{array}$} & \multirow{2}{*}{$\begin{array}{l}\text { Identification of waste } \\
\text { (muda) of time of } \\
\text { workers due to ineffi- } \\
\text { cient workplace design }\end{array}$} & Number of identified muda in ompaany & \multirow[t]{2}{*}{$\%$} & \multirow[t]{2}{*}{$100 \%$} \\
\hline & & & Total number of potential mudain RPA & & \\
\hline \multirow[t]{2}{*}{15} & \multirow{2}{*}{$\begin{array}{l}\text { Innova- } \\
\text { tion } \\
\text { level }\end{array}$} & \multirow{2}{*}{$\begin{array}{l}\text { The number of imple- } \\
\text { mented innovations in } \\
\text { the enterprise proposed } \\
\text { by employees }\end{array}$} & Number of accepted innovation per period $t$ & \multirow[t]{2}{*}{$\%$} & \multirow[t]{2}{*}{$100 \%$} \\
\hline & & & Total number of proposed innovation in period $t$ & & \\
\hline
\end{tabular}

Source: [Golińska et al. 2015, Kosacka 2014]

Each indicator was defined according to the Catalogue of the indicator's elements.

Taking into consideration that the data for the calculation of the indicators should be readily available in the company and if the data are not available in the form of numerical values, the indicator can be calculated based on the expert knowledge of decision-makers, the SIS consisted of quantitative and qualitative indicators $\left(I_{2}, I_{4}, I_{6}, I_{7}\right)$. The questionnaires to measure levels of qualitative indicators were described in details in work of Golińska et al.[2015]

The presented SIS is a dedicated solution for sustainability assessment which was practically used in remanufacturing business in Poland.

\section{SUMMARY}

There is observed the growing concern on sustainability, including the SD concept introduction at the company level. The SD is not an option but it is a requirement of the competiveness, what results in managing the SD. To manage a company including social, economic and ecologic aspects there is a challenge of assessing sustainability performance.

Authors have described an indicators based assessment method, which is appropriate for assessing current sustainability state. Previous studies show that there are different approaches towards the development of sustainability assessment tools, but there was no example of SIS dedicated for the remanufacturing companies which process ELVs.

The process of SIS establishment was time-consuming and required overcoming many difficulties involved in complying with the guidelines of a good indicator (ACRUS) as well as challenges related to SIS (from C1 till C7). 
In authors opinion the proposed set of indicators is a useful tool for measuring the three dimensions of sustainable development, which is adapted to the business specific of company remanufacturing car parts, in the context of support for future decisions aimed at improving the sustainability.

SIS should be verified in practice, which is a prerequisite to undertake further research in this area.

\section{ACKNOWLEDGMENTS}

This paper refers to the research financed by the Narodowe Centrum Badan i Rozwoju NCBiR (National Centre for Research and Development) in the framework of the German-Polish cooperation for sustainable development, project "Sustainability in remanufacturing operations (SIRO)", grant no. WPN/2/2012

\section{REFERENCES}

[1] Assefa G., Frostell B.: Social sustainability and social acceptance in technology assessment: A case study of energy technologies, Technology in Society, 29(1),2007, pp. 63-78.

[2] Azapagic A.: Developing a framework for sustainable development indicators for the mining and minerals industry, Journal of cleaner production,12(6), 2014, pp 639-662

[3] Bartkowiak P.: Idea zrównoważonego rozwoju jako jeden ze sposobów zarządzania przedsiębiorstwem / red. Piotr Bartkowiak.[Aut.] Bartkowiak Piotr. [W :] Współczesne zarządzanie organizacją: determinanty koncepcji zrównoważonego rozwoju - Kalisz : Państwowa Wyższa Szkoła Zawodowa (PWSZ) w Kaliszu, 2010. s. 51-74

[4] Bernaciak A., Gaczek W. M.: Ekonomiczne aspekty ochrony środowiska, Wydawnictwo AE, 2002

[5] Brent A., Labuschagne C.: Social indicators for sustainable project and technology life cycle management in the process industry $(13 \mathrm{pp}+4)$, The International Journal of Life Cycle Assessment, 11(1), 2006, pp. 3-15.

[6] Cooper R.G., EdgettS.J.: Maximizing productivity in production innovation. Res. Technol. Manag., 51, 2008, pp. 47-58.

[7] Diefenbacher H. : Gerechtigkeit und Nachhaltigkeit. Zum Verhältnis von Ethik und Ökonomie. Darmstadt: Wissenschaftliche Buchgesellschaft, 2001

[8] Dobrzański, G., Szymańska, E.: Przedsiębiorstwa Zrównoważone w Województwie Podlaskim-Ujęcie Modelowe i Praktyczne. The Economist, 2013.

[9] Ehrenfeld J.R.: Sustainability needs to be attained, not managed, Sustain. Sci. Pract. Policy 4, 2008, pp.1-11.

[10] Famielec J.: Zrównoważony rozwój w zarządzaniu strategicznym przedsiębiorstwa, [w:] Zrównoważony rozwój w przedsiębiorstwie i jego otoczeniu, red. A. Wasiak, G. Dobrzański, Wydawnictwo Politechnika Białostocka, Białystok, 2005

[11] Friedman M.: The Social Responsibility of Business is to Increase its Profits, The New York Times Magazine, 1970, http://www.mvopat.people.ysu.edu/courses/business_ethics/business_ethics_readings/Social_ Responsibility_Friedman.pdf [access: 11.02.2016]

[12] Gallopin G.C.: Indicators and their use: Information for decision-making. In Sustainability Indicators, Report of the Project on Indicators of Sustainable Development; Moldan, B., Billharz, S., Eds.; John Wiley \& Sons: Chichester, UK, 1997. 
[13] Golinska P., Kosacka M., Mierzwiak R., Werner-Lewandowska K.: Grey decision making as a tool for the classification of the sustainability level of remanufacturing companies, Journal of Cleaner Production, 105, 2015, pp. 28-40.

[14] Griffin R.W., (2010) Podstawy zarządzania organizacjami, PWN, Warszawa.

[15] Hejduk I.K., Grudzewski W.M.: Koncepcja sustainability wyzwaniem współczesnego zarządzania [w:] Koncepcja sustainability wyzwaniem współczesnego zarządzania, I. K. Hejduk (red)., Warszawa, 2014.

[16] Jeżowski P. : Rozwój zrównoważony we współczesnych koncepcjach ekonomicznych, [w]: Poskrobko B., Kozłowski S. (red.) Zrównoważony rozwój. Wybrane problemy teoretyczne i implementacja w świetle dokumentów Unii Europejskiej. Studia nad zrównoważonym rozwojem - tom 1, Komitet „Człowiek i Środowisko” przy prezydium PAN, BiałystokWarszawa, 2005

[17] Kistowski M.: Regionalny model zrównoważonego rozwoju i ochrony środowiska Polski a strategie rozwoju województw. Uniwersytet Gdański, 2003.

[18] Kosacka M. Opracowanie systemu społecznych wskaźników zrównoważonego rozwoju (SSDIS) dla przedsiębiorstw przetwarzających pojazdy wycofane $\mathrm{z}$ eksploatacji-studium przypadku, Gospodarka Materiałowa i Logistyka, (6 (CD)),2014, s. 71-77.

[19] Kozłowski, J. :Optimal allocation of resources to growth and reproduction: implications for age and size at maturity, Trends in Ecology \& Evolution, 7(1), 1992, s.15-19.

[20] Kudłak R.: Realizacja koncepcji zrównoważonego rozwoju poprzez systemy zarządzania środowiskowego w przedsiębiorstwach w Polsce. Bogucki Wydawnictwo Naukowe, 2008.

[21] Lawler John; Bilson Andy: Social Work Management and Leadership : Managing Complexity with Creativity, Routledge, 2013

[22] McKenzie S.: Social sustainability: towards some definitions. Hawke Research Institute Working Paper Series No 27, 2004, http://w3.unisa.edu.au/hawkeinstitute/ publications/downloads/wp27.pdf [access: 15.04.2016]

[23] Meadows D. H.: Indicators and information systems for sustainable polishdevelopment,1998, https://www-auth.uwrf.edu/SCISCD/upload/Indicators-Information.pdf [access: 10.04.2016]

[24] Mikłaszewski A.: Ekorozwój-rozwój zrównoważony, Prace Naukowe Instytutu Górnictwa Politechniki Wrocławskiej. Studia i Materiały, 87(28), 2000, s. 39-46.

[25] Möller L.: Zrównoważony rozwój w aspekcie ekologicznym, ekonomicznym i społecznym [w:] Kryński, A., Kramer, M., \& Caekelbergh, A. F. (Eds.). Zintegrowane zarządzanie środowiskiem: systemowe zależności między polityką, prawem, zarządzaniem i techniką. Wolters Kluwer Polska, 2013, s. 68-90.

[26] Ness B., Urbel-Piirsalu E., Anderberg S., Olsson L.: Categorising tools for sustainability assessment, Ecological economics, 60(3),2007, pp. 498-508.

[27] Nidumolu R., Prahalad C. K., Rangaswami M. R.: Why sustainability is now the key driver of innovation, Harvard business review,87(9), 2009, pp. 56-64.

[28] Ogrodnik R.: Identyfikacja aspektów środowiskowych jako podstawa opracowania systemu zarząadzania środowiskowego w przedsiębiorstwie górniczym. Komputerowo zintegrowane zarządzanie, Oficyna Wydawnicza Polskiego Towarzystwa Zarządzania Produkcją, Opole, 2011, http://ptzp.org.pl/files/konferencje/kzz/artyk_pdf_2011/077.pdf [access: 04.03.2016]

[29] Piontek B.: Koncepcja rozwoju trwałego i zrównoważonego Polski. PWN. Warszawa, 2002.

[30] Pittel K.: Nachhaltige Entwicklung und Wirtschaftswachstum, WiSt, Wirtschaftswissenschaftliches Studium 33 (9), 2004, pp. 537-544.

[31] Porter M.E. : America's green strategy, Scientific American, 264 (4), 1991

[32] Przechodzień W.: Zrównoważone przedsiębiorstwo, Poltext, 2013 
[33] Przychodzeń J., Przychodzeń W.: Koncepcja zrównoważonego przedsiębiorstwa. Ekonomika i Organizacja Przedsiębiorstwa, (5), 2011, s. 57-65.

[34] Raftowicz-Filipkiewicz M.: Konkurencyjność przedsiębiorstw ukierunkowanych na zrównoważony rozwój w warunkach kryzysu gospodarczego, Ekonomia-Wroclaw Economic Review, 19(1), 2013, s. 49-57

[35] Roche C.: Impact Assessment for Development Agencies: Learning to Value Change. Oxfam GB, 1999

[36] Schiavo-Campo S.: Performance in the public sector", Asian Journal of political Science, 1999, 7(2).

[37] Singh S., Olugu E.U., Musa S.N.: Development of sustainable manufacturing performance evaluation expert system for small and medium enterprises, Procedia CIRP 40,2016, pp. 609-614.

[38] Szadziewska A.: Przejawy realizacji koncepcji rozwoju zrównoważonego w działalności przedsiębiorstw. Prace i Materiały Wydziału Zarządzania Uniwersytetu Gdańskiego, Zeszyty Naukowe Uniwersytetu Gdańskiego, Zagadnienia Ekonomiki Przemysłu, (4/4), 2010, s. 155 168.

[39] Śleszyński J. : Rola wskaźników realizacji trwałego rozwoju, Zrównoważony rozwój w teorii ekonomii i praktyce Prace naukowe AE we Wrocławiu, Nr.1190, 2007, s. 99-113.

[40] Tan H. X., Yeo Z., Ng. R., Tjandra T. B., Song B.: A sustainability indicator framework for Singapore small and medium-sized manufacturing enterprises, Procedia CIRP, 29, 2015, pp. 132-137.

[41] Waas T., Hugé J., Block T., Wright T., Benitez-Capistros F., Verbruggen A.: Sustainability Assessment and Indicators: Tools in a Decision-Making Strategy for Sustainable Development. Sustainability, 6(9), 2014, pp. 5512-5534. MDPI AG. http://dx.doi.org.scopus.han3 .library.put.poznan.pl/10.3390/su6095512 [access: 09.04.2016]

[42] Wasiak A., Dobrzański G.: Zrównoważony rozwój w przedsiębiorstwie i jego otoczeniu, CSDEM, Białystok, 2005

[43] Wodzikowski C.: Zrównoważony rozwój w dyskursie nad koncepcją ochrony przyrody w Polsce po 1989 r. Problemy Ekorozwoju: studia filozoficzno-sozologiczne, 4(1), 2009, s. 83-92.

\section{SYSTEM WSKAŹNIKÓW ZRÓWNOWAŻONEGO ROZWOJU (SIS) DLA PRZEDSIĘBIORSTW REMANUFACTURINGOWYCH Z BRANŻY MOTORYZACYJNEJ - WYNIKI BADAŃ}

Celem artykułu jest prezentacja wyników badań nad opracowaniem Systemu Wskaźników Zrównoważonego Rozwoju (Sustainable Development Indicators System SDIS) dla oceny przedsiębiorstw zajmujących się remanufacturingiem części samochodowych. Badania przeprowadzane były w ramach projektu SIRO „Zrównoważony rozwój w procesie wtórnego wytwarzania" (ang. Sustainability in Remanufacturing Operations) stanowiącego przykład polsko - niemieckiej współpracy na rzecz zrównoważonego rozwoju realizowanego na Wydziale Inżynierii Zarządzania Politechniki Poznańskiej w latach 2012-2014. Zrównoważony rozwój to koncepcja oparta na 3 filarach: społecznym, środowiskowym i ekonomicznym, które pozostają ze sobą w relacji trade - off. Implikuje to trudności w realizacji koncepcji. Innym problemem w realizacji zasad zrównoważonego rozwoju jest trudność w ocenie zgodności podejmowanych działań z założeniami koncepcji. W opinii autorów, aby przedsiębiorstwa mogły realizować koncepcję zrównoważonego rozwoju, koniecznym jest zbudowanie systemu umożliwiającego jego pomiar. Służyć ma to, 
z jednej strony ocenie stanu obecnego, a z drugiej wyznaczaniu kierunków działań podejmowanych w przyszłości. Autorzy artykuły w ramach przeprowadzonych badań, zaproponowali system 15 wskaźników pozwalający na ocenę każdego z 3 filarów zrównoważonego rozwoju. Autorzy, wnioskując na podstawie przeprowadzonych badań literaturowych, postawili tezę wskazującą na brak kompleksowego systemu oceny zrównoważonego rozwoju. Dotychczasowe badania prezentują możliwość oceny poszczególnych filarów zrównoważonego rozwoju, jednak wadą tych rozwiązań jest mnogość i niejednoznaczność proponowanych metodyk. W związku z powyższym w ramach przeprowadzonych badań, autorzy zaproponowali jednoznaczną metodykę pozwalającą dokonać oceny zrównoważonego rozwoju dla przedsiębiorstw przetwarzających pojazdy wycofane z eksploatacji.

Słowa kluczowe: zrównoważony rozwój, ocena zrównoważonego rozwoju ocena wskaźnikowa zrównoważonego rozwoju

DOI: $10.7862 /$ rz.2016.mmr.47

Tekst złożono w redakcji: październik 2016

Przyjęto do druku: grudzień 2016 